\title{
ТРУДОВЫЕ ПРАКТИКИ
}

\section{Job Resources and Organizational Commitment in Finnish Company Units in Finland and Russia}

\author{
T. SAARI*, H. MELIN**
}

*Tiina Saari-Postdoctoral Researcher, Tampere University, Finland. Address: Kalevantie 4, 33100, Tampere, Finland. E-mail: tiina.saari@tuni.fi

**Harri Melin - Professor, Tampere University, Finland. Address: Kalevantie 4, 33100, Tampere, Finland. E-mail: harri.melin@tuni.fi

Citation: Saari T., Melin H. (2021) Job Resources and Organizational Commitment in Finnish Company Units in Finland and Russia. Mir Rossii, vol. 30, no 2, pp. 48-71. DOI: 10.17323/1811-038X-2021-30-2-48-71

This article compares organizational commitment and its predictors in the units of two Finnish companies operating in Finland and Russia. The research questions are: which of the two countries has a higher level of organizational commitment and do different job resources affect the organizational commitment of Finnish and Russian employees?

The research data was collected in a web survey $(N=636)$. Cross tabulation, variance analysis and binary logistic regression analysis were used as the analysis methods.

Russian employees were more committed in both organizations compared with their Finnish counterparts.

Based on the regression analysis, development opportunities and the support of colleagues influenced the organizational commitment of both Finnish and Russian employees. Opportunities for influencing one's work also affected commitment among Finns. By contrast, satisfaction with management or salary had no statistically significant effect on organizational commitment in either of the countries.

Both in Finland and in Russia organizations must invest in employee well-being, especially development possibilities and supportive work communities in order to enhance affective organizational commitment. This study adds to the limited comparative research on Finland and Russia and the predictors of affective organizational commitment in these countries.

Keywords: organizational commitment, affective commitment, normative commitment, continuance commitment, Job Demands-Resources Model, comparative research 


\section{Introduction}

Russia is an important market for Finnish companies and several Finnish companies have key production facilities in Russia. In 2019, Russia was Finland's fifth most important export and second most important import partner [Statistics Finland 2020]. Over 500 Finnish companies operate in Russia, employing a total of nearly 50,000 local employees [Finnish-Russian Chamber of Commerce 2018; Confederation of Finnish Industries 2018]. When a Finnish company operates in Russia, its daily practices need to reconcile two distinct business cultures. Finnish business culture creates the general framework for the operations of a unit of a Finnish-owned company, alongside which Russian customs and employees' expectations define organizational processes.

One may therefore ask how wellbeing at work is manifested in a comparison of the units of a Finnish organization operating in Finland and Russia. This article compares the job resources and organizational commitment at the Finnish and Russian units of two Finnish-owned organizations. The theoretical premises for the study were the job demands-resources model (JD-R model) [Demerouti et al. 2001] and the three-component model of organizational commitment [Meyer, Allen 1991].

The study is focused on the private sector. In Russia, the private sector has been much bolder in renewing its structures and operating approaches compared to stateowned businesses and public administration. The workplace culture and leadership styles of the private sector in Russia are partly similar to those of Western countries (e.g. [Balabanova et al. 2015]). However, the results of studies concerning the private sector cannot be generalized to depict working life in Russia on the whole, as state-owned businesses and public administration have not developed as far (e.g. [Gurvich 2016]).

Culture affects how employees experience and react to organizational processes and organizational practices and, consequently, their commitment [Meyer et al. 2012; Fischer, Mansell 2009; Williamson et al. 2009]. As Finland and Russia represent two different work cultures, it is useful to compare the organizational commitment of Finnish and Russian employees and to explore how the foreign - in this context Finnishbackground of a company affects employees' commitment.

In Russia, workplace mobility was exceptionally high in the 1990s and 2000 s [Gimpelson, Lippoldt 1999; Tan et al. 2007]. Nonetheless, unemployment has been steadily declining and employment rates have remained high [Gimpelson, Kapeliushnikov 2011; Balabanova et al. 2016]. In addition, low unemployment and a shortage of trained workers have increased the competition for employees, and skilled workers have been quick to change workplaces for reasons such as salary, particularly in large cities [Karhunen et al. 2008, p. 198]. In Russia, foreign companies are perceived as desirable employers as they provide their employees with good social benefits and above-average wages [Kozina 2010]. By contrast, in Finland, there is less workplace mobility, and competition based on salary is mainly focused on industries with shortages of skilled workers, such as ICT. In fact, the average length of employment relationships has increased in the Finnish labor market [Sutela, Lehto 2013, p. 27].

Based on these premises, it could be estimated that engaging the commitment of employees in Finnish organizations operating in Russia is more challenging in Russia than it is in Finland. Our research question is whether Finnish employees are more committed to their organization than their Russian counterparts. We analyze all three components 
of Meyer and Allen's three-component model of organizational commitment: affective, normative and continuance commitment [Meyer, Allen 1991]. The second research question is whether different factors of job resources predict the affective organizational commitment of Finnish and Russian employees. Affective commitment was chosen for this analysis because it represents the employees' emotional attachment to the organization and it therefore most affects employee action [Mercurio 2015]. To answer the latter question, satisfaction with management, salary, support from colleagues, opportunities for development and influence at work of Finnish and Russian employees are analyzed. This article increases knowledge of organizational commitment and its antecedents which management may make use of when developing ways to enhance organizational commitment.

Previous comparative studies [Saari et al. 2017; Saari et al. 2018a; Saari et al. 2018b] have observed that Finland's private sector employees are more satisfied with management and have higher work engagement compared with their Russian counterparts. No previous comparative studies have been conducted concerning organizational commitment between Finland and Russia.

\section{Russian and Finnish work life}

A large number of foreign companies and their affiliates operate in the Russian market, and according to some estimates, they produce up to one third of all consumer products in Russia [Gurkov 2014]. When a company's affiliate operates in a foreign country, the branch will at least partly follow the business culture of the parent company's country of origin. This involves introducing the parent country's operating models and practices to the foreign affiliate. However, this is not always a smooth transfer. For instance, in comparisons of the operations of Nordic companies in Russia and the Baltic states, companies do not always fully introduce the Nordic operating models to their foreign affiliates [Sippola 2011; Sippola 2016]. The examined companies did not transfer the participation and negotiation opportunities they provide to their employees in the parent country to their foreign branches [Sippola 2011; Sippola 2016]. Transnational companies should not transfer operating models as they are, but should adapt their leadership styles to each affiliate country's culture and cultural expectations to achieve maximum profitability. For instance, increasing opportunities for influence among employees in highly hierarchical countries may even reduce the company's profitability [Newman, Nollen 1996].

During the last decades, the structures and operating approaches of companies have also changed in Russia. The Russian labour market has simultaneous features of stability and change. One can argue that working life in Russia has become more similar to that in Western Europe. Nonetheless, Russian business activities and working life continue to be considerably marked by characteristics and practices from the socialist era, such as bureaucracy, corruption, the major significance of informal personal networks, and an unofficial labor market [Kosonen, Parviainen 2010; Fey, Shekshnia 2011]. Moreover, Russia is a society of relationships, and good relationship networks are vital for companies [Ledeneva 2006]. Finnish companies operating in Russia also acknowledge the necessity of relationships with the authorities and other companies [Heininen et al. 2008; Kosonen, Heliste 2006]. 
From the perspective of this research, the employers' paternalistic relationship with employees is a particularly interesting and essential feature of Russian working life. In the Soviet Union, companies were in charge of many services that are managed by municipalities in Finland. Soviet companies organized daycare, built housing and were also responsible for the infrastructure of industrial communities, including road networks. They also provided vocational education for their employees. After the dissolution of the Soviet Union, Russian companies stopped many of their previous social practices. However, there are some signs of a return to paternalism (cf. [Melin 1996; Melin 2005]). Employers continue to provide their employees with social benefits, including childcare and healthcare services. Social services provided by companies have proven to be a good means to increase employee commitment, and foreign-owned companies have also continued this practice [Kozina 2010; Kosonen, Parviainen 2010, p. 149].

In countries with high power distances, leadership has traditionally been hierarchical and employees have been given few opportunities for involvement in formal decision-making concerning the organization [Gimpelson, Kapeliushnikov 2011; Efendiev et al. 2014]. Historically, the Russian leadership style has been based on an authoritarian, top-down approach (e.g. [Melin 1996]). According to some studies Russian work organizations still remain hierarchical and authoritarian in their management styles [Nikula, Chernysh 2020; Gurvich 2016]. However, as a result of the general modernization of society, the Russian leadership approach is currently undergoing changes as a new generation is assuming leadership roles. This new generation of managers has grown up in post-socialist Russia and is also accustomed to dealing with international business partners (e.g. [Balabanova et al. 2015; Akindinova et al. 2016]). The Russian leadership style can hardly be summarized into a single paradigm, or even two, such as the old and new way. In fact, the situation would be better illustrated by heterogeneity, i.e. a variety of leadership styles [Balabanova et al. 2017].

In Russia, companies have a considerable need for commitment from their employees. This is challenged by the high turnover rate, competition for highly trained employees, and poor workforce availability resulting from low birth rates and high mortality among working-aged men [Karhunen at al. 2008; Bondarenko 2015]. One way to enhance commitment is salary: Russian wage earners usually rate the external values of work higher than the internal ones. This means that they value salary and other rewards more than issues such as interesting work [Anikin 2011; Balabanova et al. 2016]. In this regard, the country differs considerably from Finland. Finnish employees pay a lot more attention to the contents of work and other internal factors. In fact, the significance of salary for workplace attachment has been in decline for over 20 years in Finland [Sutela, Lehto 2013, p. 24].

In Finland, as in other Nordic countries, the quality of work has been considered among the best in Europe. For instance, the autonomy of employees, and the opportunities for development and influence provided for them have ranked very high internationally [Mustosmäki 2017; Parent-Thirion et al. 2007; Gallie 2003]. In 2015, Finland ranked highest in Europe in opportunities for influencing work, participating in decision-making and attending training provided by the employer [Eurofund 2017]. While the traditional characteristics of the Russian leadership style - an authoritarian approach and managers' extensive prerogatives - are widely known, Finnish leadership is harder to pin down, as no single Finnish leadership approach has been identified [Seeck 2008, pp. 284-297]. According to Seeck, knowledge about international leadership has been quickly adopted 
in Finland to respond to problems emerging at each stage of working life development [Seeck 2008]. While the country's working life no longer struggles with employee commitment, approaches such as wellbeing management are used in an effort to support employees' capabilities for renewal and learning [Seeck 2008]. Finland's situation and position are considerably different from Russia in the development of both leadership and overall wellbeing at work.

\section{Organizational commitment and job resources}

Organizational commitment is a widely examined topic and Meyer and Allen's [Meyer, Allen 1991] model of organizational commitment is the most widely used and tested theory on the subject. It has also been tested in non-Western contexts, including in Russia [Lovakov 2016]. The model comprises affective, normative and continuance commitment. Affective commitment refers to an emotional attachment to and identification with the organization and a desire for continuing work in the organization. Normative commitment is based on a sense of obligation, meaning that leaving the organization would break the norms of the individual employee or his or her community. This results in social pressure to remain with the organization. At the core of continuance commitment is the consideration of the costs and benefits of leaving or remaining with an organization. Leaving often involves changes that require resources, staying with an organization is often considered easier than leaving it, resulting in employees who are even slightly unsatisfied with their jobs remaining with their employer [Meyer, Allen 1991, p. 78].

Organizational commitment has a variety of positive impacts on the organization and its employees. From the perspective of the organization, commitment positively correlates with quality, and negatively with absences, intention to change jobs and changing jobs [Ng, Feldman 2014; Riketta 2002; Cohen, Golan 2007; Meyer et al. 2002]. From the employee perspective, commitment is negatively connected with stress and work-family conflict, and positively connected with issues such as career success [Ng, Feldman 2014; Meyer et al. 2002].

At the organizational level, the conditions for commitment include support from managers [Meyer et al. 2002]. In Russia, satisfaction with salary has been linked to low intentions to change workplaces [Balabanova et al. 2016]. In addition to the reasons related to the organization and individuals, cultural values and operating approaches also affect commitment [Meyer et al. 2012]. However, in some studies, power distances had no effect on commitment [Fischer, Mansell 2009]. Additionally, Meyer and his research group [Meyer et al. 2012] noticed that cultural values explained a large share of the variation in normative and affective variation but did not influence continuance commitment levels. There have been very few comparisons on organizational commitment between Finland and Russia. In fact, Russia is seldom included in international comparative studies.

Some comparative studies have observed the organizational commitment of Finns to be fairly low. For example, in a comparison of 54 countries and 9 regions, affective commitment was highest in Central Europe, represented in the study by Germany, France, the Netherlands and Belgium, and lowest in the Nordic countries, of which Finland ranked the lowest [Meyer et al. 2012]. In another comparison of 16 European countries, the affective commitment of Finns was below average [Turunen 2014]. 
In Turunen's study, rewards were the strongest condition for commitment in the majority of the studied countries. However, in Finland, the most important condition for commitment was good manager-employee relationships. Neither of these studies included Russia.

The JD-R model has been widely used in describing wellbeing at work, and the model is applied in the present study. In the JD-R model, demands refer to the effort, challenges and stress factors of work, while resources refer to the factors enabling employees to achieve the goals set for work and sustain the demands of work (e.g. [Demerouti et al. 2001; Bakker, Demerouti 2016]). Job resources contribute to the motivational process, in which their role involves helping employees act in their work roles and achieve their work objectives [Bakker, Demerouti 2016].

Job demands, such as time pressures, emotional challenges and conflicts pertaining to roles may lead to burnout and other health issues [Halbesleben, Buckley 2004]. Job resources, such as social support, feedback and autonomy are connected to the motivational process, which leads to work engagement and organizational commitment [Demerouti et al. 2001; Hakanen et al. 2008].

This study is focused on job resources, particularly as a condition for affective commitment. A choice was made to select affective commitment for further analysis instead of continuance commitment and normative commitment, as the emotional attachment to the workplace included in affective commitment makes it the most significant form of commitment with most considerable effect on the activities of employees [Mercurio 2015].

The resources analyzed in this study include satisfaction with management, support from colleagues, having influence at work and opportunities for development. In addition to these, the opinions of the fairness of salaries are examined because according to earlier studies salary is a central value for Russian workers and it is connected with turnover intentions [Anikin 2011; Balabanova et al. 2016].

Management, support from colleagues, having influence and opportunities for development all are important parts of the organizational culture. According to Perceived Organizational Support Theory (POST) the support that has been obtained from the organization supports employee wellbeing. In an organizational culture which supports employees, they are fairly treated, appreciated and they have the possibility of affecting their work [Rhoades, Eisenberger 2002]. Perceived organizational support can affect positively to the working conditions of organizations, which may promote welfare and positive work attitudes [Mauno, Ruokolainen 2008, p. 156]. Organizational commitment is reflected in a positive work attitude and therefore POST serves as a good starting point to analyze the predictors of organization commitment.

\section{Research data and methods}

The research data was collected in a survey conducted in two large, Finnish-owned companies. The first of them is a manufacturing company and the second operates in the service sector. Both companies have been operating in Russia for decades. No further details on the companies and their operations shall be provided in the present context as the companies agreed to participate in the research cooperation on the condition that they remain anonymous. The survey was conducted in 2016 and 2017 in units 
operating in Finland and Russia. In total, 180 responses were obtained from the Finnish and 234 from the Russian units of the industrial company. 158 responses were obtained from the Finnish and 64 from the Russian units of the service company. The total number of respondents included in the data was 636. More information about the respondents is provided in Table 1.

Table 1. Research data

\begin{tabular}{|l|c|c|c|c|}
\hline \multirow{2}{*}{ Age (mean) } & \multicolumn{2}{|c|}{ Industrial organization } & \multicolumn{2}{c|}{ Service organization } \\
\cline { 2 - 5 } & Finnish units & Russian units & Finnish units & Russian units \\
\hline Years of working in this organization (mean) & 47 & 33 & 38 & 32 \\
\hline Gender: Women & $52 \%$ & $51 \%$ & $67 \%$ & $70 \%$ \\
\hline \multicolumn{1}{|c|}{ Men } & $48 \%$ & $49 \%$ & $33 \%$ & $30 \%$ \\
\hline Contract type: Fixed term contract & $6 \%$ & $8 \%$ & $6 \%$ & $7 \%$ \\
\hline Permanent contract & $94 \%$ & $92 \%$ & $94 \%$ & $93 \%$ \\
\hline Responses (n) & 180 & 234 & 158 & 64 \\
\hline Response rate & $36 \%$ & $20 \%$ & $12 \%$ & $26 \%$ \\
\hline
\end{tabular}

The survey was carried out as an online questionnaire. At the beginning respondents were provided with information on the purpose of the research and the confidentiality of the respondents' identity. The average age of the respondents from the industrial organization was 47 in Finland and 33 in Russia. The average age of the respondents in the service sector was 38 in Finland and 32 in Russia. On average, the employees had worked for the industrial organization for 17 years in Finland and 6 years in Russia. In the service organization, the respective numbers were 9 years in Finland and 4 in Russia. Both organizations had a nearly identical share of fixed-term employees, from 6 to 8 per cent. In both organizations, the majority of respondents were female, 51 per cent in the Russian units of the industrial organization to 70 per cent at the Russian units of the service organization. The response rates were quite low (12-36\%) in both organizations, which may have affected the results. The reasons behind the low rates may be for example that employees, particularly in the Finnish service organization, do not have time to answer surveys a work or they do not have easy access to the internet during work hours. In addition, it is possible that those who have a low level of wellbeing and possibly also the lowest organizational commitment, are not interested in answering surveys. Response rates of web surveys are usually lower compared to other data collection methods [Blumenberg, Barros 2018] and this kind of low response rates for internet surveys are quite normal in Finland. Even though it is therefore not possible to make extensive generalizations about the countries based on the data, the results give a rare example of similarities and differences of the attitudes of employees in Russian and Finnish work units. 


\section{Table 2. Variables used in the analysis}

\begin{tabular}{|c|c|c|c|}
\hline Variable & Questions/Statements & $\begin{array}{l}\text { Response } \\
\text { alternative }\end{array}$ & $\begin{array}{l}\text { Summed } \\
\text { variable alpha }\end{array}$ \\
\hline $\begin{array}{l}\text { Affective } \\
\text { commitment }\end{array}$ & $\begin{array}{l}\text { I feel that the problems of my workplace are also } \\
\text { my problems; } \\
\text { I feel that I am "part of the family" at this workplace; } \\
\text { Working in this particular organization has major personal } \\
\text { importance for me. }\end{array}$ & $\begin{array}{l}1 \text { fully agree } \\
5 \text { fully disagree }\end{array}$ & $\begin{array}{l}\text { Finland } 0.661 \\
\text { Russia } 0.719\end{array}$ \\
\hline $\begin{array}{l}\text { Continuance } \\
\text { commitment }\end{array}$ & $\begin{array}{l}\text { Leaving this workplace would have a negative impact } \\
\text { on too many things in my life; } \\
\text { I do not have a lot of options that would make me consider } \\
\text { changing my workplace; } \\
\text { If I had not sacrificed so much for this workplace, } \\
\text { I might consider changing it. }\end{array}$ & $\begin{array}{l}1 \text { fully agree... } \\
5 \text { fully } \\
\text { disagree... }\end{array}$ & $\begin{array}{l}\text { Finland } 0.595 \\
\text { Russia } 0.694\end{array}$ \\
\hline $\begin{array}{l}\text { Normative } \\
\text { commitment }\end{array}$ & $\begin{array}{l}\text { I feel obligated to continue working for my current } \\
\text { employer; } \\
\text { Even if it would be in my best interest, I would not feel right } \\
\text { leaving this workplace now; } \\
\text { I would feel guilty if I changed my workplace now. }\end{array}$ & $\begin{array}{l}1 \text { fully agree... } \\
5 \text { fully } \\
\text { disagree... }\end{array}$ & $\begin{array}{l}\text { Finland } 0.853 \\
\text { Russia } 0.791\end{array}$ \\
\hline $\begin{array}{l}\text { Satisfaction } \\
\text { with } \\
\text { management }\end{array}$ & $\begin{array}{l}\text { My manager supports and encourages me; } \\
\text { My manager praises me for good job performance; } \\
\text { My manager is inspiring; } \\
\text { My manager trusts his/her employees. }\end{array}$ & $\begin{array}{l}1 \text { fully agree... } \\
5 \text { fully } \\
\text { disagree... }\end{array}$ & $\begin{array}{l}\text { Finland } 0.911 \\
\text { Russia } 0.924\end{array}$ \\
\hline $\begin{array}{l}\text { Opportunities } \\
\text { for influence }\end{array}$ & $\begin{array}{l}\text { How much can you influence the following issues: } \\
\text { The order in which you complete your tasks? } \\
\text { Your work pace? } \\
\text { Your working hours? } \\
\text { The amount of amount? }\end{array}$ & $\begin{array}{l}1 \text { a lot, } \\
2 \text { somewhat } \\
\text { a lot, } \\
3 \text { somewhat } \\
\text { little, } \\
4 \text { not at all. }\end{array}$ & $\begin{array}{l}\text { Finland } 0.817 \\
\text { Russia } 0.799\end{array}$ \\
\hline $\begin{array}{l}\text { Support } \\
\text { provided } \\
\text { by the work } \\
\text { community }\end{array}$ & $\begin{array}{l}\text { The atmosphere open and community spirit good at your } \\
\text { workplace; } \\
\text { I am supported and encouraged by your coworkers when } \\
\text { work seems difficult; } \\
\text { I feel that you are a valued member of your work } \\
\text { community. }\end{array}$ & $\begin{array}{l}1 \text { fully agree... } \\
5 \text { fully } \\
\text { disagree... }\end{array}$ & $\begin{array}{l}\text { Finland } 0.864 \\
\text { Russia } 0.877\end{array}$ \\
\hline $\begin{array}{l}\text { Opportunities } \\
\text { for } \\
\text { development }\end{array}$ & $\begin{array}{l}\text { My opportunities for developing my skills at my current } \\
\text { workplace are... }\end{array}$ & $\begin{array}{l}1 \text { good, } \\
2 \text { moderate, } \\
3 \text { poor }\end{array}$ & \\
\hline $\begin{array}{l}\text { Fairness of } \\
\text { salary }\end{array}$ & $\begin{array}{l}\text { Do you feel that the salary you are paid is fair if compared } \\
\text { to wages paid in other professions? }\end{array}$ & \multicolumn{2}{|c|}{$\begin{array}{l}\text { My salary is } \\
\text { clearly higher than it should be. } \\
\text { slightly higher than it should be. } \\
\text { approximately at the right level. } \\
\text { slightly lower than it should be. } \\
\text { clearly lower than it should be. }\end{array}$} \\
\hline
\end{tabular}

Meyer and Allen's model of organizational commitment was used in measuring organizational commitment and involved asking for responses for nine statements on a scale of 1-5 (1 fully agree, 5 fully disagree) [Meyer, Allen 1991]. The questions of the commitment indicators and alpha values given to the summed variables are presented in Table 2.

The background variables for commitment explore the resources of the JD-R model [Demerouti et al. 2001]. The resources included satisfaction with managers, the support of the work community, and opportunities for influencing work and professional development. 
Experiences of the fairness of salary were also investigated as salary is an important factor for Russians [Anikin 2011; Balabanova et al. 2016]. The questions in their original forms, indicators and alpha values of the summed variables are presented in Table 2.

The research methods used were variance analysis, cross tabulation and binary logistic regression analysis. In the variance analysis, i.e. comparison of means, the Bonferroni correction was selected as the post hoc analysis tool as the group variances in the population were of equal size (i.e. F-test $\mathrm{p}>0,05$ ). Logistic regression was selected as the model used in the regression analysis instead of linear regression, as logistic regression does not require a normal distribution of the examined variable [Tabacknick, Fidell 2001, p. 517]. In this data, affective commitment has a nearly normal distribution for Finland; however, this is not the case for Russia. The regression analysis explains the predictors of high and fairly high affective commitment. This group of highly and fairly highly committed includes the respondents who answered that they somewhat or fully agreed with all three questions of all summed variables. As the organizational background variables of the analysis are continuous variables (or, in the present context, Likert-scale variables interpreted as continuous variables), beta coefficients must be interpreted instead of odds ratio (OR); however, unlike OR, the coefficients cannot be organized based on size [Best, Wolf 2015, p. 157]. Therefore, the findings do not give grounds for determining whether, for instance, the support provided by the work community has a stronger impact on commitment than development opportunities. However, the analysis shows which background variables are connected to strong affective commitment. No multicollinearity that would impede the analysis was found between the variables in the analysis (Correlation tables, Appendix).

\section{Results}

\section{Affective, normative and continuance commitment}

Based on a comparison of the means, affective commitment is the strongest form of commitment in all the units, although its strength varies (Figures 1 and 2). Affective commitment is strongest in the Russian service units, where the mean was 4.1 on a scale of 1-5. The Finnish industrial units had the lowest mean (3.0).

According to the Bonferroni post-hoc test, the differences in the strength of affective commitment were statistically significant $(p<0,05)$ between all groups except when comparing the Russian industrial units with the Finnish service units $(\mathrm{p}=1)$ and Russian service units $(\mathrm{p}=0,085)$.

Continuance commitment, i.e. the commitment to stay or leave the organization, is not as strongly divided between the organizations. The means of all of the units are close to 3. The differences in the means are not statistically significant with the exception of a comparison between the Finnish service units and the Russian industrial units $(p=0,004)$.

In contrast, there was more variation in the normative commitment, i.e. commitment based on a sense of obligation to stay. The average level of normative commitment was lowest in the Finnish industrial units, where the mean was 2.2, and highest at the Russian service units (3.2). 
Based on the Bonferroni post-hoc test, the differences in means were statistically significant in all comparisons other than between the Finnish service and industrial units $(\mathrm{p}=0,076)$ and between the Russian service and industrial units $(\mathrm{p}=1,000)$.

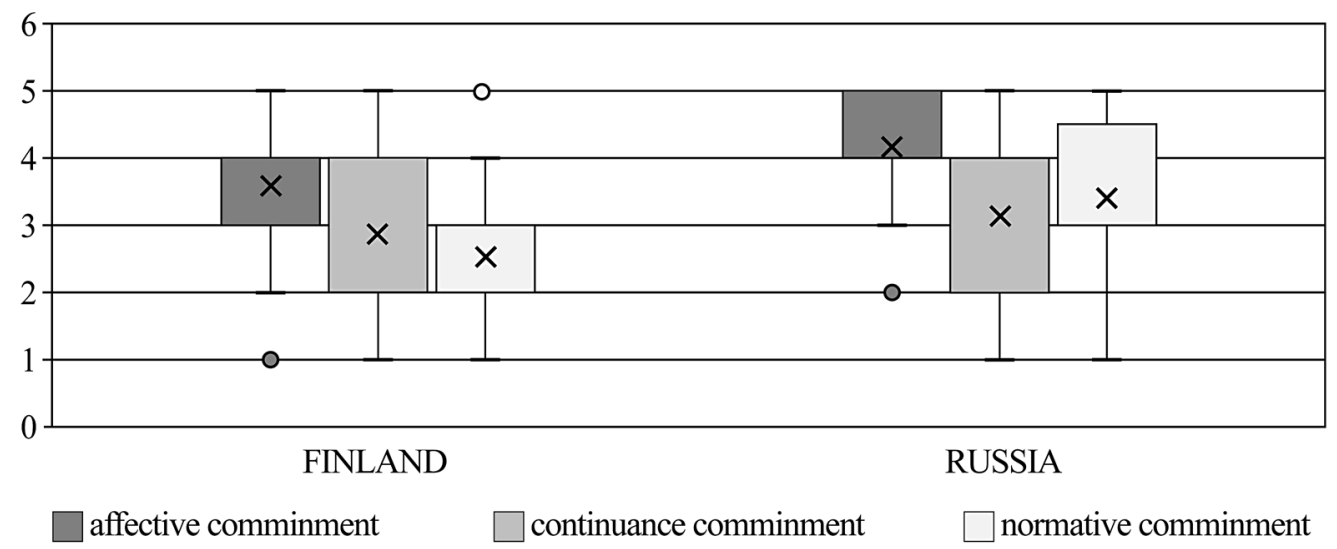

Figure 1. Deviation of affective, normative and continuance commitment in Finnish and Russian service units

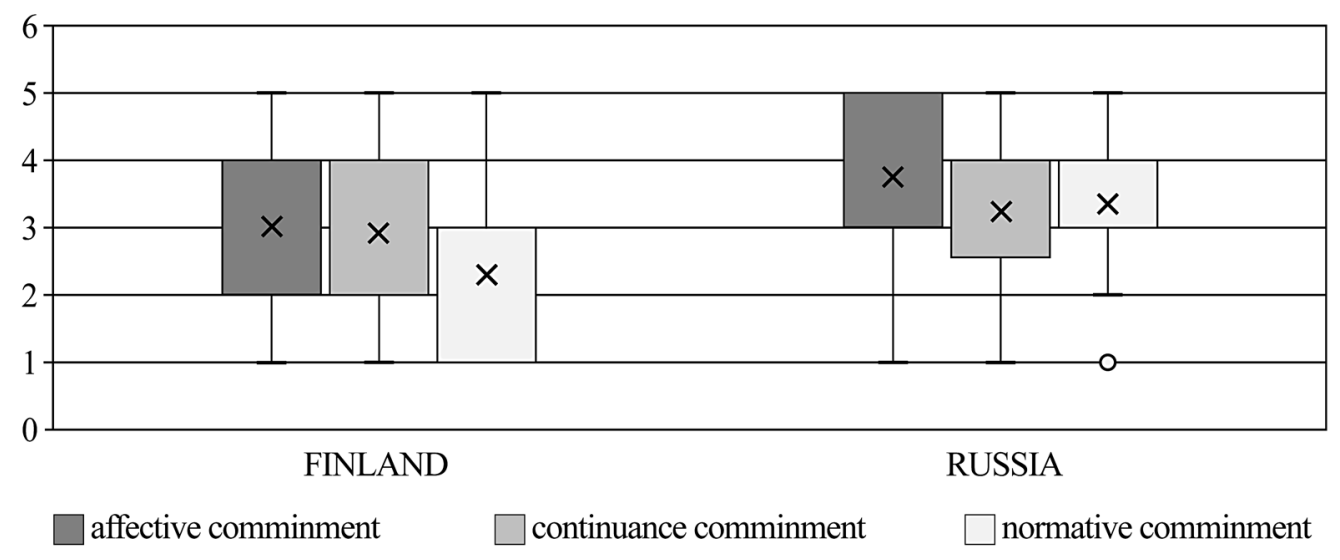

Figure 2. Deviation of affective, normative and continuance commitment in Finnish and Russian industrial units

In both organizations, a statistically significant difference was found between the units operating in different countries at the levels of affective and normative commitment. The employees in both Russian units were more committed than those working in the Finnish units of the same organizations. Commitment was lowest in the Finnish industrial units. The employees were not committed to their organization based on emotional reasons, continuity or a sense of obligation. In contrast, in the Russian units of the same 
company, affective commitment was second highest and continuance commitment the highest. This means that the employees perceive the organization as a good enough employer and consider the costs and/or effort of leaving too high. The employees at the Russian service units were most affectively committed. The commitment of the employees in the Finnish service units is also best characterized by affective commitment, which had the highest average score. However, continuance and normative commitment at the units was below the mean average.

\section{Job resources}

In the following section, descriptive methods are used to analyze work resources: satisfaction with management, support from colleagues, having an influence and opportunities for development. The results are presented in Table 3. The effects of these factors on commitment are then analyzed.

Satisfaction with management: The employees at the Russian units of both firms were more satisfied with management compared to their Finnish counterparts. 75 per cent of the staff at the Russian units in both industries are very or fairly satisfied with management. At the Finnish service units, the share of very or fairly satisfied employees is 66 per cent. At the Finnish industrial unit, less than 50 per cent of the employees belonged to the very satisfied group. The differences are statistically significant.

Support from colleagues: The employees in the Russian units of both organizations were more satisfied with the support provided by their colleagues compared to the Finnish respondents. At the Russian industrial units, 75 per cent of the employees were very or fairly satisfied with the support provided by colleagues. In Finland, the respective share was around 60 per cent. At the Russian units of the service company, nearly 90 per cent, and in Finland 75 per cent, were very or fairly satisfied. The differences are statistically significant.

Opportunities for influence: At the service organization, slightly less than 50 per cent of the employees felt that they could influence their work a lot or somewhat. However, there was a bigger difference between the units of the industrial organization. About 50 per cent of the employees at the Russian units felt able to affect their work a lot or somewhat, while only around 40 per cent employees at the Finnish units agreed. These results were not statistically significant.

Opportunities for development: In both companies, there were differences between the countries in the employees' opportunities for developing their skills. Results were statistically significant. At the Russian units of the industrial organization, 40 per cent of employees considered their opportunities for development as good; at the Finnish units, only around 20 per cent of the employees agreed. In the service organization, over 50 per cent of the employees at the Russian units, and around 40 per cent of employees at the Finnish units, considered their opportunities for development as good.

Satisfaction with salary: In both countries, employees were unsatisfied with their salaries. The Finnish and Russian employees' dissatisfaction with salary was similar in both companies. Only about 30 per cent of the employees at the Finnish industrial units and around 25 per cent in the Russian industrial units considered their salary 
to be at a roughly accurate level. Around 75 per cent of the respondents said that their salary was lower than it should be, except for employees at the Finnish industrial units where 68 per cent said their salary was low. In conclusion, the great majority of the employees were unsatisfied with their salary. However, these findings were not statistically significant.

Table 3. Cross tabulation of job resources in Finland and Russia

\begin{tabular}{|c|c|c|c|c|c|}
\hline & $\begin{array}{l}\text { SERVICE: } \\
\text { RUSSIA }\end{array}$ & $\begin{array}{c}\text { SER- } \\
\text { VICE: } \\
\text { FINLAND }\end{array}$ & $\begin{array}{l}\text { INDUS- } \\
\text { TRY: } \\
\text { RUSSIA }\end{array}$ & $\begin{array}{c}\text { INDUS- } \\
\text { TRY: } \\
\text { FINLAND }\end{array}$ & $\mathbf{P}=$ \\
\hline \multicolumn{6}{|l|}{ SATISFACTION WITH MANAGEMENT } \\
\hline Very or fairly satisfied & $74 \%$ & $66 \%$ & $73 \%$ & $44 \%$ & 0,000 \\
\hline Neither satisfied nor dissatisfied & $17 \%$ & $19 \%$ & $17 \%$ & $32 \%$ & \\
\hline Very or fairly dissatisfied & $9 \%$ & $15 \%$ & $11 \%$ & $24 \%$ & \\
\hline $\begin{array}{l}\text { SUPPORT PROVIDED BY } \\
\text { THE WORK COMMUNITY }\end{array}$ & & & & & 0,000 \\
\hline Very or fairly satisfied & $86 \%$ & $77 \%$ & $76 \%$ & $59 \%$ & \\
\hline Neither satisfied nor dissatisfied & $11 \%$ & $18 \%$ & $13 \%$ & $26 \%$ & \\
\hline Very or fairly dissatisfied & $4 \%$ & \multicolumn{2}{|c|}{$\begin{array}{c}5 \% \\
11 \%\end{array}$} & $15 \%$ & \\
\hline OPPORTUNITIES FOR INFLUENCE & & & & & 0,403 \\
\hline Very or fairly satisfied & $45 \%$ & $44 \%$ & $49 \%$ & $38 \%$ & \\
\hline Neither satisfied nor dissatisfied & $48 \%$ & $44 \%$ & $44 \%$ & $53 \%$ & \\
\hline Very or fairly dissatisfied & $7 \%$ & $11 \%$ & $8 \%$ & $9 \%$ & \\
\hline OPPORTUNITIES FOR DEVELOPMENT & & & & & 0,000 \\
\hline Good & $53 \%$ & $37 \%$ & $43 \%$ & $22 \%$ & \\
\hline Moderate & $36 \%$ & $40 \%$ & $44 \%$ & $48 \%$ & \\
\hline Poor & $11 \%$ & $23 \%$ & $14 \%$ & $29 \%$ & \\
\hline SALARY & & & & & 0,501 \\
\hline Salary higher than it should be & $2 \%$ & $1 \%$ & $1 \%$ & $2 \%$ & \\
\hline Approximately correct salary level & $22 \%$ & $24 \%$ & $24 \%$ & $30 \%$ & \\
\hline Salary lower than it should be & $76 \%$ & $75 \%$ & $76 \%$ & $68 \%$ & \\
\hline
\end{tabular}


Table 4. Logistic regression analysis. Finland. 1=high level of organizational commitment

\begin{tabular}{|l|c|c|c|}
\hline & B & S.E. & Wald \\
\hline Management (ref. dissatisfied) & $-0,01$ & 0,15 & 0 \\
\hline Opportunities for development (ref. poor) & $1,00 * * *$ & 0,23 & 18,89 \\
\hline Opportunities for influence (ref. poor) & $0,40 *$ & 0,21 & 3,71 \\
\hline Support of colleagues (ref. dissatisfied) & $0,62 * * *$ & 0,19 & 10,56 \\
\hline Salary (ref. dissatisfied) & $-0,16$ & 0,19 & 0,69 \\
\hline Age (ref. advanced age) & 0,02 & 0,02 & 1,36 \\
\hline Gender (ref. female) & 0,25 & 0,29 & 0,74 \\
\hline Organization (ref. industrial) & $0,98 * * *$ & 0,32 & 9,7 \\
\hline Tenure (ref. long) & $-0,02$ & 0,02 & 0,83 \\
\hline Constant & $6,68 * * *$ & 1,15 & 33,93 \\
\hline Hosmer and Lemeshow Test & 0,554 & & \\
\hline Cox \& Snell R Square & 0,267 & & \\
\hline Nagelkerke R Square & 0,359 & & \\
\hline$* * * \mathbf{p}=\mathbf{0 , 0 0 0 * *} \mathbf{p}=<\mathbf{0 , 0 1} * \mathbf{p}=<\mathbf{0 , 0 5}$ & & & \\
\hline
\end{tabular}

Table 5. Logistic regression analysis. Russia. 1=high level of organizational commitment

\begin{tabular}{|l|c|c|c|}
\hline & B & S.E. & Wald \\
\hline Management (ref. dissatisfied) & 0,11 & 0,22 & 0,25 \\
\hline Opportunities for development (ref. poor) & $0,98 * * *$ & 0,33 & 9,04 \\
\hline Opportunities for influence (ref. poor) & $-0,37$ & 0,27 & 1,81 \\
\hline Support of colleagues (ref. dissatisfied) & $1,39 * * *$ & 0,29 & 23,27 \\
\hline Salary (ref. dissatisfied) & 0,11 & 0,28 & 0,15 \\
\hline Age (ref. advanced age) & 0,05 & 0,03 & 2,67 \\
\hline Gender (ref. female) & 0,31 & 0,43 & 0,53 \\
\hline Organization (ref. industrial) & 0,2 & 0,58 & 0,12 \\
\hline Tenure (ref. long) & 0,07 & 0,05 & 1,75 \\
\hline Constant & $-8,52 * * *$ & 1,68 & 25,86 \\
\hline Hosmer and Lemeshow Test & 0,572 & & \\
\hline Cox \& Snell R Square & 0,362 & & \\
\hline Nagelkerke R Square & 0,513 & & \\
\hline$* * * \mathbf{p}=\mathbf{0 , 0 0 0 * *} \mathbf{p}=<\mathbf{0 , 0 1} * \mathbf{p}=<\mathbf{0 , 0 5}$ & & & \\
\hline
\end{tabular}


The impact of job resources on commitment: regression analysis

Next, Russian and Finnish employees are compared on the basis of whether the same characteristics predict high commitment. Binary logistic regression analysis was used to analyze the impacts of management, support from colleagues, opportunities for influence and opportunities for development on affective organizational commitment in Finland and in Russia. In addition to these organizational variables, the respondents' gender, age, organization type and tenure were included in the analysis.

Development opportunities and the support of colleagues are connected to the commitment of both Finnish and Russian employees. In Finland, the opportunities for influence were also connected to commitment. In Finland, there was difference between the results of the two organizations: working in the service organization predicted stronger commitment. The management, the perceived fairness of salary, age, gender and tenure did not have a statistically significantly effect on commitment in either of the countries (See Tables 4 and 5).

\section{Discussion and conclusions}

This article compared the commitment and job resources at the units of two Finnish companies operating in Finland and in Russia and analyzed the impact of job resources on commitment. According to the findings, the employees of the units operating in Russia are more committed to their jobs than the employees working at the Finnish units of the same organizations. There was also a difference in all job resources between the organizations. Employees in the service sector were more satisfied with each of the resources compared to the employees of the industrial organization. Development opportunities and the support of colleagues influence the affective commitment of both Finnish and Russian employees. Opportunities for influencing one's work also affected the affective commitment among Finns.

Affective commitment and satisfaction with job resources was higher among the employees at the Russian units than their Finnish counterparts. The employees of the Russian units of the Finnish-owned companies were very satisfied with the management. Their satisfaction may be at least partly explained by the fact that the companies' operating culture, which mostly manifests as the work of managers in the employees' daily practice, is based on the Finnish leadership style. This means that the management of the companies may include practices that are still uncommon in Russian working life, including open communications about organizational issues.

A Western or, in the present context, Finnish business culture and management style is also likely to contribute to a more positive assessment of work the community among Russian employees compared to their Finnish counterparts. When a company's operations are transparent and its management is based on less hierarchy and high employee involvement, as in the Nordic leadership style, employees are not in competition with one another, which may result in a good working atmosphere. According to a study on flexible work arrangements in Finland, employee wellbeing is high at workplaces 
marked by a strong sense of trust and reciprocity. This is also apparent in the company's productivity and profitability [Mamia, Melin 2005, pp. 137-138].

Based on the regression analysis, development opportunities and the support of colleagues influence the commitment of both Finnish and Russian employees. Opportunities for influencing one's work also affected commitment among Finns. The lack of a statistically significant impact of management on employee commitment was a somewhat surprising result. In both countries, commitment includes a personal factor, namely the opportunity for development (in Finland also opportunities for influence), and a communal dimension. This result can be explained through the theory of affective commitment, as this is focused on the organization and work community as a "family" of sorts. Even though managers are part of this community, good relationships with coworkers may be considered more important in the organizations included in this study.

Another unexpected result was the lack of statistically significant effect between the perceived fairness of salary and commitment in both countries. According to several previous studies, salary is a key factor, particularly to Russian workers (e.g. [Anikin 2011; Balabanova et al. 2016]), and it has also been observed to play a more important role than communality [Kozina 2010]. However, communality emerged as a more significant factor than salary in the present study, at least in relation to commitment.

The operating culture of a company is not always transferred in its original form to the country where the affiliate operates (e.g. [Sippola 2011; Sippola 2016]). The transfer of operating models may also be complicated by cultural differences between countries, such as power distances [Newman, Nollen 1996]. How can we then explain the difference in the satisfaction of Finnish and Russian employees? In a study comparing the quality of working life experienced by employees at the units of a Finnish company in Finland and Poland, satisfaction was higher among the employees at the Polish unit compared with the Finnish employees [Järvensivu et al. 2011]. This finding is interesting as previous studies have indicated that the quality of working life is high in Finland and low in Poland. This finding was explained with the concept of moral agreement. Expectations for work vary in different countries. As a result, the employees at the Polish unit perceived good quality of working life differently than the Finnish employees [Järvensivu et al. 2011, p. 33].

Similarly, the present study may assume that the expectations of well-being at work are generally lower among Russian employees, which would explain satisfaction at the workplaces conforming to Finnish standards. On the other hand, foreign-owned companies are considered to be desirable employers in Russia according to previous studies. Compared to Russian companies, they have different leadership styles, generally they pay higher salaries, and offer better social benefits [Kozina 2010]. From this viewpoint, Russians may have fairly high expectations towards a foreign employer, in spite of which the respondents were satisfied with their Finnish employer.

We may also assume that the experiences of Russian employees of the Finnish companies' low hierarchy, transparency of decision-making and treatment of employees are significant enough to produce strong commitment on their own. Finnish employees may take these for granted and they do not significantly affect Finns commitment to their workplace.

The fact that the opportunity for development and the support of colleagues, influenced employees' commitment, indicates that the Finnish and Russian employees have similar expectations towards work. In this regard, the expectations of Russian 
employees towards working life are approaching those of Western employees, Finnish ones in the present context. The results are also linked to POST and its idea that the support obtained from the organization promotes employee wellbeing and positive work attitudes, such as organizational commitment [Rhoades, Eisenberger 2002; Mauno, Ruokolainen 2008].

On the basis of these results, both in Finland and in Russia the companies should invest in employee well-being, especially development possibilities and supportive work communities in order to enhance affective organizational commitment. In Russia, there is strong competition for skilled workers [Balabanova et al. 2016 etc.] and Finnish and other foreign organizations may retain their employees by offering them good educational opportunities and by emphasizing the value of a good work community.

This study produced new knowledge about the commitment of the staff of two companies operating in two countries and the factors affecting this. However, it must be noted that this study was limited by the relatively small scope of the available data and the inclusion of only two organizations and a fairly low response rate. It is therefore not possible to make extensive generalizations about the countries based on the data. Nevertheless, as by way of example, we may use the data to demonstrate the differences between the countries and the strong status of foreign-owned companies as employers. Despite this, there is reason to continue and expand the comparison of Finnish and Russian working life, and Russia's participation in international comparative studies is required to obtain comparative data on the country's working life.

\section{References}

Akindinova N., Kuzminov Y., Yasin E. (2016) Russia's Economy: Before the Long Transition. Russian Journal of Economics, vol. 2, no 3, pp. 219-245.

Anikin V.A. (2011) Work in the Lives of Russian. Sociological Research, vol. 50, no 6, pp. 3-16.

Bakker A.B., Demerouti E. (2016) Job Demands-resources Theory: Taking Stock and Looking Forward. Journal of Occupational Health Psychology, vol. 22, no 3, pp. 273-285.

Balabanova E., Efendiev A., Ehrnrooth M., Koveshnikov A. (2015) Idiosyncrasy, Heterogeneity and Evolution of Managerial Styles in Contemporary Russia. Baltic Journal of Management, vol. 10, no 1, pp. 2-29.

Balabanova E., Efendiev A., Ehrnrooth M., Koveshnikov A. (2016) Job Satisfaction, Blat and Intentions to Leave among Blue-Collar Employees in Contemporary Russia. Baltic Journal of Management, vol. 11, no 1, pp. 21-43.

Balabanova B., Rebrov A., Koveshnikov A. (2017) Managerial Styles in Privately Owned Domestic Organizations in Russia: Heterogeneity, Antecedents, and Organizational Implications. Management and Organization Review, vol. 14, no 1, pp. 37-72.

Best H., Wolf C. (2015) Logistic Regression. The Sage Handbook of Regression Analysis and Causal Inference (eds. Best H., Wolf C.), Los Angeles: Sage, pp. 827-854.

Blumenberg C., Barros A.J.D. (2018) Response Rate Differences Between Web and Alternative Data Collection Methods for Public Health Research: A Systematic Review of the Literature. International Journal Public Health, vol. 63, no 6, pp. 765-773.

Bondarenko N. (2015) The Nature of the Current and Anticipated Shortage of Professional Skills and Qualities of Workers in the Russian Labor Market. Russian Education and Society, vol. 57, no 3, pp. 119-145.

Buchko A., Weinzimmer L., Sergeyev A. (1998) Effects of Cultural Context on the Antecedents, Correlates, and Consequences of Organizational Commitment: A Study of Russian Workers. Journal of Business Research, vol. 43, no 3, pp. 109-116. 
Cohen A., Golan R. (2007) Predicting Absenteeism and Turnover Intentions by Past Absenteeism and Work Attitudes. Career Development International, vol. 12, no 5, pp. 416-432.

Confederation of Finnish Industries (2018). Venäjä - suuret markkinat, heikko talouskehitys ja pakotteet [Russia - Large Market, Poor Economic Development and Sanctions]. Available at: https://ek.fi/mita-teemme/kauppapolitiikka/venaja/, accessed 15.10.2018 (in Finnish).

Demerouti E., Bakker A.B., Nachreiner F., Schaufeli W.B. (2001) The Job Demands-resources Model of Burnout. Journal of Applied Psychology, vol. 86, no 3, pp. 499-512.

Efendiev A.G., Balabanova E.S., Lyubykh Zh.S. (2014) Russian Employees' Participation in Decision Making in Domestic and Foreign-Owned Companies. Sotsiologicheskie Issledovaniya, no 12, pp. 41-50 (in Russian).

Eurofound (2017). Sixth European Working Conditions Survey - Overview Report. Publications Office of the European Union, Luxembourg. Available at: https://www.eurofound.europa.eu/publications/report/2016/working-conditions/sixtheuropean-working-conditions-survey-overview-report, accessed 13.10.2020.

Fey C.F., Shekshnia S. (2011) The Key Commandments for Doing Business in Russia. Organizational Dynamics, vol. 40, no 1, pp. 57-66.

Finnish-Russian Chamber of Commerce (2018). Trade between Finland and Russia. Available at: https://www.svkk.fi/suomen-ja-venajan-valinen-kauppa/, accessed 13.10.2020.

Fischer R., Mansell A. (2009) Commitment across Cultures: A Meta-Analytical Approach. Journal of International Business Studies, vol. 40, no 8, pp. 1339-1358.

Gallie D. (2003) The Quality of Working Life: Is Scandinavia Different? European Sociological Review, vol. 19, no 1, pp. 61-79.

Gimpelson V., Kapeliushnikov R. (2011) Labor Market Adjustment: Is Russia Different? IZA Discussion Paper. No. 5588, Bonn: IZA.

Gimpelson V., Lippoldt D. (1999) Labour Turnover in Russia: Evidence from the Administrative Reporting of Enterprises in Four Regions. Transition Economics Series No. 4, Vienna: Institute for Advanced Studies.

Gurkov I. (2014) Management Practices in Russian Manufacturing Subsidiaries of Foreign Multinational Corporations: Challenging Some Beliefs about Contemporary Russian Industrial Management. Post-Communist Economies, vol. 26, no 2, pp. 220-240.

Gurkov I. (2016) Human Resource Management in Russian Manufacturing Subsidiaries of Multinational Corporations. Post-Communist Economies, vol. 28, no 3, pp. 353-372.

Gurvich E. (2016) Institutional Constraints and Economic Development. Russian Journal of Economics, vol. 2, no 4, pp. 349-374.

Hakanen J., Schaufeli W., Ahola K. (2008) The Job Demands-Resources model: A Threeyear Cross-lagged Study of Burnout, Depression, Commitment, and Work Engagement. Work \& Stress, vol. 22, no 3, pp. 224-241.

Halbesleben J.R.B., Buckley M.R. (2004) Burnout in Organizational Life. Journal of Management, vol. 30, no 6, pp. 859-879.

Heininen P., Mashkina O., Karhunen P., Kosonen R. (2008) Leningradin lääni yritysten toimintaympäristönä - pk-sektorin näkökulma [Leningrad Oblast as an Operating Environment for Companies - the Perspective of the SME Sector]. Publications of the Helsinki School of Economics B-88, Helsinki (in Finnish).

Järvensivu A., Piirainen P., Nikkanen R., Viitala E. (2011) Työntekijöiden kokema työelämän laatu suomalaisen teollisuuskonsernin Suomen ja Puolan yksiköissä [The Quality of Working Life Experienced by Employees in the Units of a Finnish Industrial Group in Finland and Poland]. Työelämän tutkimus, vol. 9, no 1, pp. 19-36 (in Finnish).

Karhunen P., Kosonen R., Logrén J., Ovaska K. (2008) Suomalaisyritysten strategiat Venäjän muuttuvassa liiketoimintaympäristössä [The Strategies of a Finnish Company in the Changing Business Environment of Russia]. Publications of the Helsinki School of Economics B-84. Available at: https://aaltodoc.aalto.fi/bitstream/handle/123456789/11017/ isbn9789524882415.pdf? sequence=1, accessed 10.10.2018 (in Finnish).

Kosonen R. (2008) Henkilösuhteet ja epävirallinen vaikuttaminen venäläisessä liiketoiminnassa [Personal Relationships and Unofficial Influence in Russian Business]. Suhteiden Venäjä [Russia - Country of Relationships] (eds. Salmenniemi S., Rotkirch A.), Helsinki: Gaudeamus, pp. 93-121 (in Finnish). 
Kosonen R., Heliste P. (2006) Bilateral Economic Relations between Finland and Russia: Finnish Firms' Experiences in Northwest Russia. The Two-level Game: Russia's Relations with Great Britain, Finland and the European Union (ed. Smith H.). Aleksanteri Series 2/2006, Helsinki: Aleksanteri Institute, pp. 205-224.

Kosonen R., Parviainen S. (2010) Viralliset ja epäviralliset käytännöt lyövät kättä venäläisessä liike-elämässä vuonna 2030 [Official and Unofficial Practices Will Shake Hands in Russian Business in 2030]. Sopimusten Venäjä 2030 [Russia 2030] (eds. Kuusi O., Smith H., Tiihonen P.). Publication of the Committee for the Future 3/2010, Helsinki, pp. 136-160 (in Finnish).

Kozina I. (2010) Transnational Corporations, Labor Relations and Trade Unions - Russian Case. Journal for Labour and Social Affairs in Eastern Europe, vol. 13, no 1, pp. 69-88.

Ledeneva A. (2006) How Russia Really Works, Ithaca: Cornell University Press.

Leppänen S., Linden M., Solanko L. (2008) Production Uncenrtainty, Enterprises' Social Responsibility and Institutional Heritage in a Post-Soviet Economy. Initiatives for discussion \#59. University of Joensuu.

Lovakov A. (2016) Antecedents of Organizational Commitment among Faculty: An Exploratory Study. Tertiary Education and Management, vol. 22, no 2, pp. 149-170.

Mamia T., Melin H. (eds.) (2005) Tietoyhteiskunta ja työorganisaatioiden muutos [Information Society and Change in Work Organizations], University of Turku (in Finnish).

Mauno S., Ruokolainen M. (2008) Organisaatiokulttuurin yhteys henkilöstön työhyvinvointiin ja työasenteisiin [The Connection of Organizational Culture to Employee Well-Being and Work Attitudes]. Työ leipälajina [Profession of a Baker] (eds. Kinnunen U., Feldt T., Mauno S.), Jyväskylä: PS-Kustannus, pp. 142-166 (in Finnish).

Melin H. (1996) Suunnitelman varjossa. Tutkimus yritysjohtajista Neuvostoliitossa ja Venäjällä [In the Shadow of the Plan. A Study of Business Leaders in the Soviet Union and Russia], Tampere: University of Tampere (in Finnish).

Melin H. (2005) Towards New Paternalism in Kondopoga. Social Structure, Public Space and Civil Society in Karelia (ed. Melin H.), Helsinki: Kikimora Publishers, pp. 61-76.

Mercurio Z. (2015) Affective Commitment as a Core Essence of Organizational Commitment. An Integrative Literature Review. Human Resource Development Review, vol. 14, no 4, pp. 389-414.

Meyer J., Allen N. (1991) A Three-Component Conceptualization of Organizational Commitment. Human Resource Management Review, vol. 1, no 1, pp. 61-89.

Meyer J., Stanley D., Herscovitch L., Topolnytsky L. (2002) Affective, Continuance, and Normative Commitment to the Organization: A Meta-analysis of Antecedents, Correlates, and Consequences. Journal of Vocational Behavior, vol. 61, no 1, pp. 20-52.

Meyer J.P., Stanley D.J., Jackson T., McInnis K., Maltin E., Sheppard L. (2012) Affective, Normative, and Continuance Commitment Levels across Cultures: A Meta-analysis. Journal of Vocational Behavior, vol. 80, no 2, pp. 225-245.

Mustosmäki A. (2017) How Bright Are the Nordic Lights? Job Quality Trends in Nordic Countries in a Comparative Perspective. Jyväskylä Studies in Education, Psychology and Social Research. No. 586, Jyväskylä: University of Jyväskylä.

Newman K., Nollen S. (1996) Culture and Congruence: The Fit between Management Practices and National Culture. Journal of International Business Studies, vol. 27, no 4, pp. 753-779.

Ng T.W.H., Feldman D.C. (2014) Subjective Career Success: A Meta-analytic Review. Journal of Vocational Behavior, vol. 85, no 2, pp. 169-179.

Nikula J., Chernysh M. (eds.) (2020) Social Distinctions in Contemporary Russia. Waiting for the Middle Class-society, London: Routledge.

Parent-Thirion A., Fernández-Macías E., Hurley J., Vermeylen G. (2007) Fourth European Working Conditions Survey. European Foundation for the Improvement of Living and Working Conditions, Luxembourg: Office for Official Publications of the European Communities.

Rhoades L., Eisenberger R. (2002) Perceived Organizational Support: A Review of the Literature. Journal of Applied Psychology, vol. 87, no 4, pp. 698-714.

Riketta M. (2002) Attitudinal Organizational Commitment and Job Performance: A Meta-analysis. Journal of Organizational Behavior, vol. 23, no 3, pp. 257-266. 
Saari T., Melin H., Balabanova E., Efendiev A. (1) (2018) Better Leadership, Higher Work Engagement? Comparative Study on Finnish and Russian Private Sector Employees. International Journal of Sociology and Social Policy, vol. 38, no 11/12, pp. 922-943.

Saari T., Sippola M., Melin H., Balabanova E., Efendiev A. (2) (2018) Comparing Finnish and Russian Work Life. Mir Rossii, vol. 27, no 2, pp. 90-108.

Saari T., Melin H., Balabanova E., Efendiev A. (2017) The Job Demands and Resources as Antecedents for Work Engagement - Comparative Research on Finland and Russia. Baltic Journal of Management, vol. 12, no 2, pp. 240-254.

Seeck H. (2008) Johtamisopit Suomessa [Management Doctrines in Finland], Helsinki: Gaudeamus (in Finnish).

Sippola M. (2011) Nordic Subsidiaries in the Baltic States: Is Model Transfer Possible? Employee Relations, vol. 33, no 4, pp. 356-374.

Sippola M. (2016) Dancing to the Tune of the Employer? Union-management Relationships at Nordic Subsidiaries in Russia. Economic and Industrial Democracy, October 4, 2016. Available at: https://journals.sagepub.com/doi/full/10.1177/0143831X16669841, accessed 9.09.2020.

Statistics Finland (2020). Trade: Biggest Import and Export Countries. Available at: https://www.tilastokeskus.fi/tup/suoluk/suoluk_kotimaankauppa en.html, accessed 9.09.2020.

Sutela H., Lehto A.-M. (2013) Työolojen muutokset 1977-2013 [Changes in Working Conditions 1977-2013], Helsinki: Statistics Finland (in Finnish).

Tabachnick B., Fidell L. (2001) Using Multivariate Statistics, Boston: Allyn and Bacon.

Tan H., Savchenko Y., Gimpelson V., Kapelyushnikov R., Lukyanova A. (2007) Skills Shortages and Training in Russian Enterprises. IZA Discussion Paper No. 2751, Bonn: IZA. Available at: http://ftp.iza.org/dp2751.pdf, accessed 10.10.2018.

Turunen T. (2014) Lack of Commitment? Work Orientations of Finnish Employees in a European Comparison. Nordic Journal of Working Life Studies, vol. 4, no 29, pp. 65-83.

Williamson I., Burnett M., Bartol K. (2009) The Interactive Effect of Collectivism and Organizational Rewards on Affective Organizational Commitment. Cross Cultural Management: An International Journal, vol. 16, no 1, pp. 28-43.

\section{Appendix tables}

\section{Table 1. Correlations/ Finnish data}

\begin{tabular}{|l|c|c|c|c|c|c|c|c|c|}
\hline Finland & $\mathbf{1 .}$ & $\mathbf{2 .}$ & $\mathbf{3 .}$ & $\mathbf{4}$ & $\mathbf{5 .}$ & $\mathbf{6 .}$ & $\mathbf{7 .}$ & $\mathbf{8 .}$ & $\mathbf{9 .}$ \\
\hline 1. Affective commitment & \multicolumn{1}{|c|}{} & & & & & & & & \\
\hline 2. Satisfaction with management & $0,324^{* *}$ & 1 & & & & & & & \\
\hline 3. Opportunities for development & $0,475^{* *}$ & $0,446^{* *}$ & 1 & & & & & & \\
\hline 4. Opportunities for influence & $0,311^{* *}$ & $0,224^{* *}$ & $0,344^{* *}$ & 1 & & & & & \\
\hline 5. Support & $0,479^{* *}$ & $0,539^{* *}$ & $0,362^{* *}$ & $0,180^{* *}$ & 1 & & & & \\
\hline 6. Fairness of salary & $0,207^{* *}$ & $0,121^{*}$ & $0,338^{* *}$ & $0,318^{* *}$ & $0,118^{*}$ & 1 & & & \\
\hline 7. Age & $-0,033$ & $-0,078$ & $-0,051$ & 0,091 & $-0,111^{*}$ & 0,067 & 1 & & \\
\hline 8. Gender & $-0,140^{*}$ & $-0,072$ & $-0,122^{*}$ & $-0,029$ & $-0,145^{* *}$ & 0,014 & $0,114^{*}$ & 1 & \\
\hline 9. Years in this organization & $-0,121^{*}$ & $-0,088$ & $-0,111^{*}$ & $-0,074$ & $-0,141^{*}$ & 0,037 & $0,706^{* *}$ & 0,073 & 1 \\
\hline
\end{tabular}


Table 2. Correlations/ Russian data

\begin{tabular}{|l|c|c|c|c|c|c|c|c|c|}
\hline Russia & $\mathbf{1 .}$ & $\mathbf{2 .}$ & $\mathbf{3}$ & $\mathbf{4}$ & $\mathbf{5 .}$ & $\mathbf{6 .}$ & $\mathbf{7 .}$ & $\mathbf{8 .}$ & $\mathbf{9 .}$ \\
\hline 1. Affective commitment & 1 & & & & & & & & \\
\hline 2. Satisfaction with management & $0,347^{* *}$ & 1 & & & & & & & \\
\hline 3. Opportunities for development & $0,371^{* *}$ & $0,316^{* *}$ & 1 & & & & & & \\
\hline 4. Opportunities for influence & $0,186^{* *}$ & $0,207^{* *}$ & $0,213^{* *}$ & 1 & & & & & \\
\hline 5. Support & $0,525^{* *}$ & $0,595^{* *}$ & $0,368^{* *}$ & $0,246^{* *}$ & 1 & & & & \\
\hline 6. Fairness of salary & $0,167^{* *}$ & $0,194^{* *}$ & $0,162^{* *}$ & 0,111 & $0,166^{* *}$ & 1 & & & \\
\hline 7. Age & $0,196^{* *}$ & 0,038 & $0,142^{*}$ & 0,043 & 0,115 & 0,042 & 1 & & \\
\hline 8. Gender & $-0,055$ & $-0,028$ & 0,063 & 0,068 & $-0,087$ & $-0,050$ & $-0,072$ & 1 & \\
\hline 9. Years in this organization & $0,166^{* *}$ & 0,033 & 0,043 & 0,083 & $0,158^{*}$ & 0,079 & $0,419^{* *}$ & $-0,090$ & 1 \\
\hline
\end{tabular}

\title{
Организационные ресурсы, возможности \\ и корпоративная лояльность
}

в подразделениях финских компаний в Финляндии и России

\author{
Т. СААРИ*, Х. МЕЛИН**
}

*Тиина Саари - научный сотрудник, Университет Тампере, Финляндия. Адрес: Kalevantie 4, 33100, Tampere, Finland. E-mail: tiina.saari@tuni.fi

***Харри Мелин - профессор социологии, Университет Тампере, Финляндия. Адрес: Kalevantie 4, 33100, Tampere, Finland. E-mail: harri.melin@tuni.fi

Цитирование: Saari T., Melin H. (2021) Job Resources and Organizational Commitment in Finnish Company Units in Finland and Russia. Mir Rossii, vol. 30, no 2, pp. 48-71. DOI: $10.17323 / 1811-038 X-2021-30-2-48-71$

В предложенной статье анализируются корпоративная лояльность и ее детерминанты в локальных подразделениях двух финских компаний, работающих на территории Финляндии и России. Осуществляется попытка ответить на исследовательские вопросы: в какой из двух стран уровень корпоративной лояльности выше, а также зависит ли лояльность финских и российских работников от тех ресурсов и возможностей, которые предоставляет организация.

Данные для исследования были собраны с помощью интернет-опроса работников, занятых на производстве в российских и финских подразделениях двух финских 
компаний ( $\mathrm{N}=636$ ). Для анализа данных использовался кросс-табуляционный, дисперсионный и регрессионный анализ. В ходе исследования установлено, что российские работники проявляют большую корпоративную лояльность, чем их финские коллеги. Результаты регрессионного анализа также показывают, что возможности роста и поддержка со стороны коллектива значительно коррелируют с уровнем лояльности как среди финнов, так и среди россиян. Корпоративной лояльности финнов также способствует возможность оказывать влияние на работу коллег. Для сравнения: статистически значимой связи между лояльностью и удовлетворенностью действиями руководства или уровнем заработной платы в ходе исследования обнаружено не было.

Выявлено, что и в Финляндии, и в России организации должны инвестировать в благополучие своих сотрудников, в возможности их роста и развития, а также в укрепление атмосферы, способствующей сотрудничеству и поддержке в трудовых коллективах.

Результаты данного исследования обогащают относительно ограниченную сравнительную литературу о России и Финляндии и о детерминантах корпоративной лояльности в этих странах.

Ключевые слова: корпоративная лояльность, аффективная лояльность, нормативная лояльность, долгосрочная лояльность, модель требований и ресурсов, сравнительные исследования

\section{Литература}

Эфендиев А.Г., Балабанова Е.С., Любых Ж.С. (2014) Участие российских работников в процессе принятия решений в отечественных и иностранных компаниях // Социологические исследования. № 12. С. 41-50.

Akindinova N., Kuzminov Y., Yasin E. (2016) Russia's Economy: Before the Long Transition // Russian Journal of Economics, vol. 2, no 3, pp. 219-245.

Anikin V.A. (2011) Work in the Lives of Russian // Sociological Research, vol. 50, no 6, pp. 3-16. Bakker A.B., Demerouti E. (2016) Job Demands-resources Theory: Taking Stock and Looking Forward // Journal of Occupational Health Psychology, vol. 22, no 3, pp. 273-285.

Balabanova E., Efendiev A., Ehrnrooth M., Koveshnikov A. (2015) Idiosyncrasy, Heterogeneity and Evolution of Managerial Styles in Contemporary Russia// Baltic Journal of Management, vol. 10, no 1, pp. 2-29.

Balabanova E., Efendiev A., Ehrnrooth M., Koveshnikov A. (2016) Job Satisfaction, Blat and Intentions to Leave among Blue-Collar Employees in Contemporary Russia // Baltic Journal of Management, vol. 11, no 1, pp. 21-43.

Balabanova B., Rebrov A., Koveshnikov A. (2017) Managerial Styles in Privately Owned Domestic Organizations in Russia: Heterogeneity, Antecedents, and Organizational Implications // Management and Organization Review, vol. 14, no 1, pp. 37-72.

Best H., Wolf C. (2015) Logistic Regression // The Sage Handbook of Regression Analysis and Causal Inference (eds. Best H., Wolf C.), Los Angeles: Sage, pp. 827-854.

Blumenberg C., Barros A.J.D. (2018) Response Rate Differences Between Web and Alternative Data Collection Methods for Public Health Research: A Systematic Review of the Literature // International Journal Public Health, vol. 63, no 6, pp. 765-773.

Bondarenko N. (2015) The Nature of the Current And Anticipated Shortage of Professional Skills and Qualities of Workers in the Russian Labor Market // Russian Education and Society, vol. 57, no 3, pp. 119-145. 
Buchko A., Weinzimmer L., Sergeyev A. (1998) Effects of Cultural Context on the Antecedents, Correlates, and Consequences of Organizational Commitment: A Study of Russian Workers // Journal of Business Research, vol. 43, no 3, pp. 109-116.

Cohen A., Golan R. (2007) Predicting Absenteeism and Turnover Intentions by Past Absenteeism and Work Attitudes // Career Development International, vol. 12, no 5, pp. 416-432.

Confederation of Finnish Industries (2018). Venäjä - suuret markkinat, heikko talouskehitys ja pakotteet [Russia - Large Market, Poor Economic Development and Sanctions] // https://ek.fi/mita-teemme/kauppapolitiikka/venaja/ (на финском).

Demerouti E., Bakker A.B., Nachreiner F., Schaufeli W.B. (2001) The Job Demands-resources Model of Burnout // Journal of Applied Psychology, vol. 86, no 3, pp. 499-512.

Eurofound (2017). Sixth European Working Conditions Survey - Overview Report. Publications Office of the European Union, Luxembourg // https://www.eurofound.europa.eu/publications/report/2016/working-conditions/sixtheuropean-working-conditions-survey-overview-report

Fey C.F., Shekshnia S. (2011) The Key Commandments for Doing Business in Russia // Organizational Dynamics, vol. 40, no 1, pp. 57-66.

Finnish-Russian Chamber of Commerce (2018). Trade between Finland and Russia // https://www.svkk.fi/suomen-ja-venajan-valinen-kauppa/

Fischer R., Mansell A. (2009) Commitment across Cultures: A Meta-Analytical Approach // Journal of International Business Studies, vol. 40, no 8, pp. 1339-1358.

Gallie D. (2003) The Quality of Working Life: Is Scandinavia Different? // European Sociological Review, vol. 19, no 1, pp. 61-79.

Gimpelson V., Kapeliushnikov R. (2011) Labor Market Adjustment: Is Russia Different? // IZA Discussion Paper. No. 5588, Bonn: IZA.

Gimpelson V., Lippoldt D. (1999) Labour Turnover in Russia: Evidence from the Administrative Reporting of Enterprises in Four Regions. Transition Economics Series No. 4, Vienna: Institute for Advanced Studies.

Gurkov I. (2014) Management Practices in Russian Manufacturing Subsidiaries of Foreign Multinational Corporations: Challenging Some Beliefs about Contemporary Russian Industrial Management // Post-Communist Economies, vol. 26, no 2, pp. 220-240.

Gurkov I. (2016) Human Resource Management in Russian Manufacturing Subsidiaries of Multinational Corporations // Post-Communist Economies, vol. 28, no 3, pp. 353-372.

Gurvich E. (2016) Institutional Constraints and Economic Development // Russian Journal of Economics, vol. 2, no 4, pp. 349-374.

Hakanen J., Schaufeli W., Ahola K. (2008) The Job Demands-Resources model: A Three-year Cross-lagged Study of Burnout, Depression, Commitment, and Work Engagement // Work \& Stress, vol. 22, no 3, pp. 224-241.

Halbesleben J.R.B., Buckley M.R. (2004) Burnout in Organizational Life // Journal of Management, vol. 30, no 6, pp. 859-879.

Heininen P., Mashkina O., Karhunen P., Kosonen R. (2008) Leningradin lääni yritysten toimintaympäristönä - pk-sektorin näkökulma [Leningrad Oblast as an Operating Environment for Companies - the Perspective of the SME Sector]. Publications of the Helsinki School of Economics B-88, Helsinki (на финском).

Järvensivu A., Piirainen P., Nikkanen R., Viitala E. (2011) Työntekijöiden kokema työelämän laatu suomalaisen teollisuuskonsernin Suomen ja Puolan yksiköissä [The Quality of Working Life Experienced by Employees in the Units of a Finnish Industrial Group in Finland and Poland] // Työelämän tutkimus, vol. 9, no 1, pp. 19-36 (на финском).

Karhunen P., Kosonen R., Logrén J., Ovaska K. (2008) Suomalaisyritysten strategiat Venäjän muuttuvassa liiketoimintaympäristössä[The Strategies of a Finnish Company in the Changing Business Environment of Russia]. Publications of the Helsinki School of Economics B-84 // https://aaltodoc.aalto.fi/bitstream/handle/123456789/11017/isbn9789524882415. pdf? sequence=1 (на финском).

Kosonen R. (2008) Henkilösuhteet ja epävirallinen vaikuttaminen venäläisessä liiketoiminnassa [Personal Relationships and Unofficial Influence in Russian Business] // Suhteiden Venäjä [Russia - Country of Relationships] (eds. Salmenniemi S., Rotkirch A.), Helsinki: Gaudeamus, pp. 93-121 (на финском). 
Kosonen R., Heliste P. (2006) Bilateral Economic Relations between Finland and Russia: Finnish Firms' Experiences in Northwest Russia // The Two-level Game: Russia's Relations with Great Britain, Finland and the European Union (ed. Smith H.). Aleksanteri Series 2/2006, Helsinki: Aleksanteri Institute, pp. 205-224.

Kosonen R., Parviainen S. (2010) Viralliset ja epäviralliset käytännöt lyövät kättä venäläisessä liike-elämässä vuonna 2030 [Official and Unofficial Practices Will Shake Hands in Russian Business in 2030] // Sopimusten Venäjä 2030 [Russia 2030] (eds. Kuusi O., Smith H., Tiihonen P.). Publication of the Committee for the Future 3/2010, Helsinki, pp. 136-160 (на финском).

Kozina I. (2010) Transnational Corporations, Labor Relations and Trade Unions - Russian Case // Journal for Labour and Social Affairs in Eastern Europe, vol. 13, no 1, pp. 69-88.

Ledeneva A. (2006) How Russia Really Works, Ithaca: Cornell University Press.

Leppänen S., Linden M., Solanko L. (2008) Production Uncenrtainty, Enterprises' Social Responsibility and Institutional Heritage in a Post-Soviet Economy. Initiatives for discussion \#59. University of Joensuu.

Lovakov A. (2016) Antecedents of Organizational Commitment among Faculty: An Exploratory Study // Tertiary Education and Management, vol. 22, no 2, pp. 149-170.

Mamia T., Melin H. (eds.) (2005) Tietoyhteiskunta ja työorganisaatioiden muutos [Information Society and Change in Work Organizations], University of Turku (на финском).

Mauno S., Ruokolainen M. (2008) Organisaatiokulttuurin yhteys henkilöstön työhyvinvointiin ja työasenteisiin [The Connection of Organizational Culture to Employee Well-Being and Work Attitudes] // Työ leipälajina [Profession of a Baker] (eds. Kinnunen U., Feldt T., Mauno S.), Jyväskylä: PS-Kustannus, pp. 142-166 (на финском).

Melin H. (1996) Suunnitelman varjossa. Tutkimus yritysjohtajista Neuvostoliitossa ja Venäjällä [In the Shadow of the Plan. A Study of Business Leaders in the Soviet Union and Russia], Tampere: University of Tampere (на финском).

Melin H. (2005) Towards New Paternalism in Kondopoga // Social Structure, Public Space and Civil Society in Karelia (ed. Melin H.), Helsinki: Kikimora Publishers, pp. 61-76.

Mercurio Z. (2015) Affective Commitment as a Core Essence of Organizational Commitment. An Integrative Literature Review // Human Resource Development Review, vol. 14, no 4, pp. 389-414.

Meyer J., Allen N. (1991) A Three-Component Conceptualization of Organizational Commitment // Human Resource Management Review, vol. 1, no 1, pp. 61-89.

Meyer J., Stanley D., Herscovitch L., Topolnytsky L. (2002) Affective, Continuance, and Normative Commitment to the Organization: A Meta-analysis of Antecedents, Correlates, and Consequences // Journal of Vocational Behavior, vol. 61, no 1, pp. 20-52.

Meyer J.P., Stanley D.J., Jackson T., McInnis K., Maltin E., Sheppard L. (2012) Affective, Normative, and Continuance Commitment Levels across Cultures: A Meta-analysis // Journal of Vocational Behavior, vol. 80, no 2, pp. 225-245.

Mustosmäki A. (2017) How Bright Are the Nordic Lights? Job Quality Trends in Nordic Countries in a Comparative Perspective Jyväskylä Studies in Education, Psychology and Social Research. No. 586, Jyväskylä: University of Jyväskylä.

Newman K., Nollen S. (1996) Culture and Congruence: The Fit between Management Practices and National Culture // Journal of International Business Studies, vol. 27, no 4, pp. 753-779.

Ng T.W.H., Feldman D.C. (2014) Subjective Career Success: A Meta-analytic Review // Journal of Vocational Behavior, vol. 85, no 2, pp. 169-179.

Nikula J., Chernysh M. (eds.) (2020) Social Distinctions in Contemporary Russia. Waiting for the Middle Class-society, London: Routledge.

Parent-Thirion A., Fernández-Macías E., Hurley J., Vermeylen G. (2007) Fourth European Working Conditions Survey. European Foundation for the Improvement of Living and Working Conditions, Luxembourg: Office for Official Publications of the European Communities.

Rhoades L., Eisenberger R. (2002). Perceived Organizational Support: A Review of the Literature// Journal of Applied Psychology, vol. 87, no 4, pp. 698-714.

Riketta M. (2002)Attitudinal Organizational Commitment and Job Performance: AMeta-analysis // Journal of Organizational Behavior, vol. 23, no 3, pp. 257-266. 
Saari T., Melin H., Balabanova E., Efendiev A. (1) (2018) Better Leadership, Higher Work Engagement? Comparative Study on Finnish and Russian Private Sector Employees // International Journal of Sociology and Social Policy, vol. 38, no 11/12, pp. 922-943.

Saari T., Sippola M., Melin H., Balabanova E., Efendiev A. (2) (2018) Comparing Finnish and Russian Work Life // Mir Rossii, vol. 27, no 2, pp. 90-108.

Saari T., Melin H., Balabanova E., Efendiev A. (2017) The Job Demands and Resources as Antecedents for Work Engagement - Comparative Research on Finland and Russia // Baltic Journal of Management, vol. 12, no 2, pp. 240-254.

Seeck H. (2008) Johtamisopit Suomessa [Management Doctrines in Finland], Helsinki: Gaudeamus (на финском).

Sippola M. (2011) Nordic Subsidiaries in the Baltic States: Is Model Transfer Possible? // Employee Relations, vol. 33, no 4, pp. 356-374.

Sippola M. (2016) Dancing to the Tune of the Employer? Union-management Relationships at Nordic Subsidiaries in Russia // Economic and Industrial Democracy, October 4, 2016 // https://journals.sagepub.com/doi/full/10.1177/0143831X16669841

Statistics Finland (2020). Trade: Biggest Import and Export Countries // https://www.tilastokeskus.fi/tup/suoluk/suoluk kotimaankauppa en.html

Sutela H., Lehto A.-M. (2013) Työolojen muutokset 1977-2013 [Changes in Working Conditions 1977-2013], Helsinki: Statistics Finland (на финском).

Tabachnick B., Fidell L. (2001) Using Multivariate Statistics, Boston: Allyn and Bacon.

Tan H., Savchenko Y., Gimpelson V., Kapelyushnikov R., Lukyanova A. (2007) Skills Shortages and Training in Russian Enterprises // IZA Discussion Paper No. 2751, Bonn: IZA // http://ftp.iza.org/dp2751.pdf

Turunen T. (2014) Lack of Commitment? Work Orientations of Finnish Employees in a European Comparison // Nordic Journal of Working Life Studies, vol. 4, no 29, pp. 65-83.

Williamson I., Burnett M., Bartol K. (2009) The Interactive Effect of Collectivism and Organizational Rewards on Affective Organizational Commitment // Cross Cultural Management: An International Journal, vol. 16, no 1, pp. 28-43. 